\title{
A methodology for the development of urban energy balances: Ten years of application to the city of Madrid
}

\author{
Javier Pérez*, Sonia Lázaro, Julio Lumbreras, Encarnación Rodríguez \\ Department of Chemical and Environmental Engineering, Universidad Politécnica de Madrid (UPM), C/ José Gutiérrez Abascal, 2, 28006 Madrid, Spain
}

\begin{abstract}
A B S T R A C T
This paper presents a methodology for the development of urban energy balances, which has been applied to the city of Madrid for the last ten years and is consistent with the guidelines of the International Energy Agency. The methodology is structured into three major modules: energy imports into the municipality, energy generation from either internal or external sources, and final energy consumption.

The paper shows results for the most recent year for which data are available, as well as historical series for the period 2006-2015. It also includes a comparison of the main energy indicators with the national situation.

The experience acquired during the ten years performing the energy balance in Madrid served to improve both the greenhouse gases and the air pollutant emission inventories, keeping their consistent with the energy balance, as well as to diagnose the city's current energy situation. This assessment was used to define a series of policies, energy saving and diversification measures, collected in different municipal plans, with the aim of decreasing the external energy dependence and the energy consumption, thereby lowering greenhouse gases emissions. Maintaining the same methodology and updating the historical series each year also allowed tracking the city's energy policy, as well as the evolution of the main energy indicators (i.e. per capita consumption and energy intensity). The methodology could be replicated in other cities worldwide, yielding improvements in their urban emission inventories.
\end{abstract}

Keywords:

Urban energy balance

Local decision-making tool

GHG inventory

Energy consumption

\section{Introduction}

It is undeniable that cities have gradually acquired more importance on the global stage in recent decades. In 2014, the population of the world living in urban settlements was estimated to be $54.5 \%$ of a total of 7.4 billion inhabitants. By 2030, urban areas are projected to host $60 \%$ of people globally (UN, 2014).

Cities occupy $3 \%$ of the planet's surface, but account for represent $67 \%$ of global primary energy demand (IEA, 2017). The combined ef fect of growing demand and depleting resources, as well as energy dependency, makes necessary a profound knowledge of energy supply and demand (OECD/IEA, 2005). Nowadays, the energy system is highly dependent on fossil fuels (Webb et al., 2016), with the ensuing con sequences on air quality (AQ) and global warming (IEA, 2017).

Increasing evidence of climate change (CC) and a growing depen dence on energy has underlined the European Union's (EU) determi nation to become a low energy economy and to have the energy con sumed be secure, safe, competitive, locally produced and environmentally friendly (EC, 2008, 2010). Although cities are not represented by an institution in the $\mathrm{EU}$, local administrations are key to managing the challenges and opportunities offered by cities, which play an emerging role in responding to $\mathrm{CC}$ and in driving low carbon energy transitions (COM, 2018; Haarstad, 2016; IEA, 2016; Rosenzweig et al., 2010). Although they can act with varying degrees of autonomy, de pending on the existence of decentralized energy planning (Parshall et al., 2010), municipal authorities are frequently better positioned to act with greater flexibility and effectiveness than central governments (Dent et al., 2016). Local authorities can prepare action plans, aware ness campaigns and specific measures to achieve more sustainable transport or buildings (Poggi et al., 2017). This has also led to the emergence of horizontal forms of co operation and alliance formation through city networks such as the C40 Large Cities Climate Group and ICLEI Local Governments for Sustainability, as well as city stated plans like Agenda 21, which attempt to develop CC responses (Haarstad, 2016; Dent et al., 2016).

There are many factors that can determine the energy use dis tribution in a city, among which are climate, global economic position, consumption patterns, quality of the built environment, urban form and

\footnotetext{
* Corresponding author.

E-mail addresses: javier.perez@etsii.upm.es (J. Pérez), slazaro@etsii.upm.es (S. Lázaro), jlumbreras@etsii.upm.es (J. Lumbreras), erodriguez@etsii.upm.es (E. Rodríguez).
} 
density and transport systems (Bhattacharyya, 2011). Therefore, it is important to understand which sectors consume more energy so as to take appropriate measures for emissions reduction (UN HABITAT, 2008).

A growing number of studies are reporting local energy consump tion, which can be divided into two broad categories: (1) those focused on specific sectors of energy use and its patterns, and (2) those that analyse total energy consumption. The former is frequently focused on the building sector (Howard et al., 2012; Moghadam et al., 2018; Niu et al., 2011; Baynes et al., 2011; Zhao et al., 2012; Pereira \& de Assis, 2013), although other studies also analyse the transport sector (Holden \& Norland, 2005; Fichera et al., 2016) or density patterns (Steemers, 2003). They normally use a combination of downscaling, aggregation, weighting or GIS statistical approaches to estimate consumption, and regression models that relate energy consumption to physical, eco nomic and social aspects of the urban environment.

The second group of studies usually classifies total energy con sumption by end use. Phdungsilp (2010), Yu et al. (2015) and Winkler et al. (2017) used the Long Range Energy Alternatives Planning (LEAP) modelling tool to simulate a range of energy policies and to predict future energy and carbon scenarios. Cai et al. (2013) did a comparative study of economy structure, energy supply and carbon emissions among a few cities, including Beijing and London. Parshall et al. (2010) used the Vulcan data to measure energy consumption and related $\mathrm{CO}_{2}$ emissions in urban areas in the United States. Liu et al. (2017) devel oped a simplified greenhouse gas policy assessment model (GHG PAM) based on the structure of annually updated and published OECD/IEDA energy balance (EB) tables. Most of these studies use data from multiple sources and energy statistics without explaining the methodology used, excluding the study by Gómez Ceballos \& Morán Perafá (2015).

The originality and novelty of this work lies in the proposal and description of an EB methodology that allows collecting the energy information of a city and structuring its flows. Energy balances are a source of reliable and consistent information on the energy situation of a region and provide an analysis of the past and present status. Preparing an energy balance requires a large amount of historical data, such as 1) energy use by sector, 2) energy production, transformation and delivery to final users, 3) technical and operating statistics of the plants and installations, 4) financial and cost information, and 5) macro economic and other social information (Bhattacharyya, 2011).

This structure allows using real energy consumption data to perform a comprehensive energy assessment of the city. The information ex tracted from the EB is very helpful in preparing emission inventories and energy projections. Moreover, it is the starting point for the deci sion making process, which allows producing regulations and action plans on sustainable energy use, CC mitigation and AQ improvement.

The objectives of this paper are to 1) describe the EB methodology, 2) apply it to a case study (city of Madrid), 3) present the results ob tained, considering the lessons learnt from 10 years of experience, and 4) show the importance and main applications of the EB.

\section{Methodology}

\subsection{General structure}

The methodology is based on a general energy generation/con sumption model, following the guidelines of the International Energy Agency (OECD/IEA, 2005) and the Spanish Ministry of Energy (MINETAD, 2018). It establishes three modules (Fig. 1):

- Module 1: external energy sources. It includes imports of energy sources that can be directly consumed as final energy or used in energy transformation processes (e.g. refining, power generation and combined heat and power (CHP)).

- Module 2: internal energy sources. It includes local energy sources like municipal solid waste (MSW) and sewage sludge (SS). These

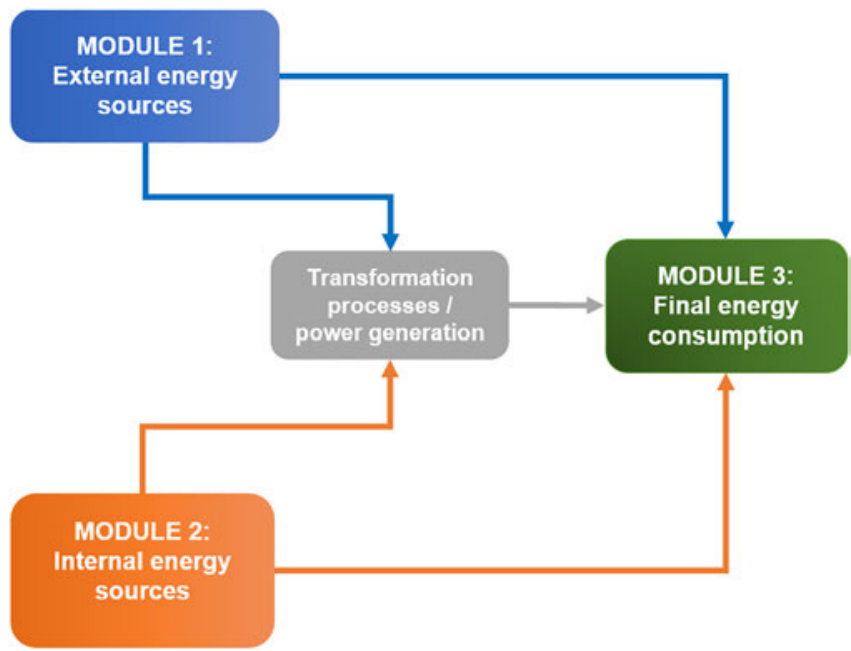

Fig. 1. General structure of the methodology proposed.

energy sources can be also used as final energy, but they are com monly used in electricity generation.

- Module 3: final energy consumption. It includes the energy con sumption of fuels, electricity and renewables in the final sectors (residential, commercial, industry, transport, etc.).

The common energy unit used is tonne of oil equivalent (toe, 1 toe $<>41,868 \mathrm{MJ})$.

\subsection{Case study}

Madrid had a population of 3,141,991 inhabitants in 2015 (INE, 2017), making it one of the most populated cities in the EU and in the top ten European regions with the highest gross domestic product (GDP) per capita (AM, 2013a). With barely $0.1 \%$ of the national area $\left(606 \mathrm{~km}^{2}\right)$, it is the most populated city and is home to $6.7 \%$ of the Spanish population.

Madrid is one of the country's most important economic, commer cial, financial and cultural centres (GDP of €95,236 million in 2015, $11.7 \%$ of Spain's GDP) (AM, 2017a).

The energetic specificities of the city are the following:

- Few sources of primary energy. The city lacks fossil fuel reserves and only has renewable resources like solar, geothermal and wind en ergy, as well as the waste valorisation.

- No large energy transformation plants for power generation or fuel production (refineries).

- Reduced electricity generation: MSW valorisation, CHP and renew able sources.

- Elevated final energy consumption. The city acts as an energy sink, as it is necessary to import a high quantity of energy to satisfy the final demand.

- "Barajas effect". A high quantity of kerosene is supplied to the Adolfo Suárez Madrid Barajas airport, which is reflected in the total energy imports. However, only a fraction is really consumed on aircrafts within the city boundaries. In the case of Madrid, only kerosene used in Landing and Take Off (LTO) cycles was considered as final energy consumption in order to be consistent with the local GHG and Air Pollutant Emission Inventory. LTO cycles include all activities near the airport that take place below a height of $914 \mathrm{~m}$, whereas "cruise" is defined as all the activities that take place above $914 \mathrm{~m}$ (EEA, 2016). However, there are other methodologies to al locate fuel consumption for GHG emission estimation with different criteria, such as Global Protocol for Community Scale GHG Emission Inventories (WRI, 2014), Publicly Available Specification (PAS) 


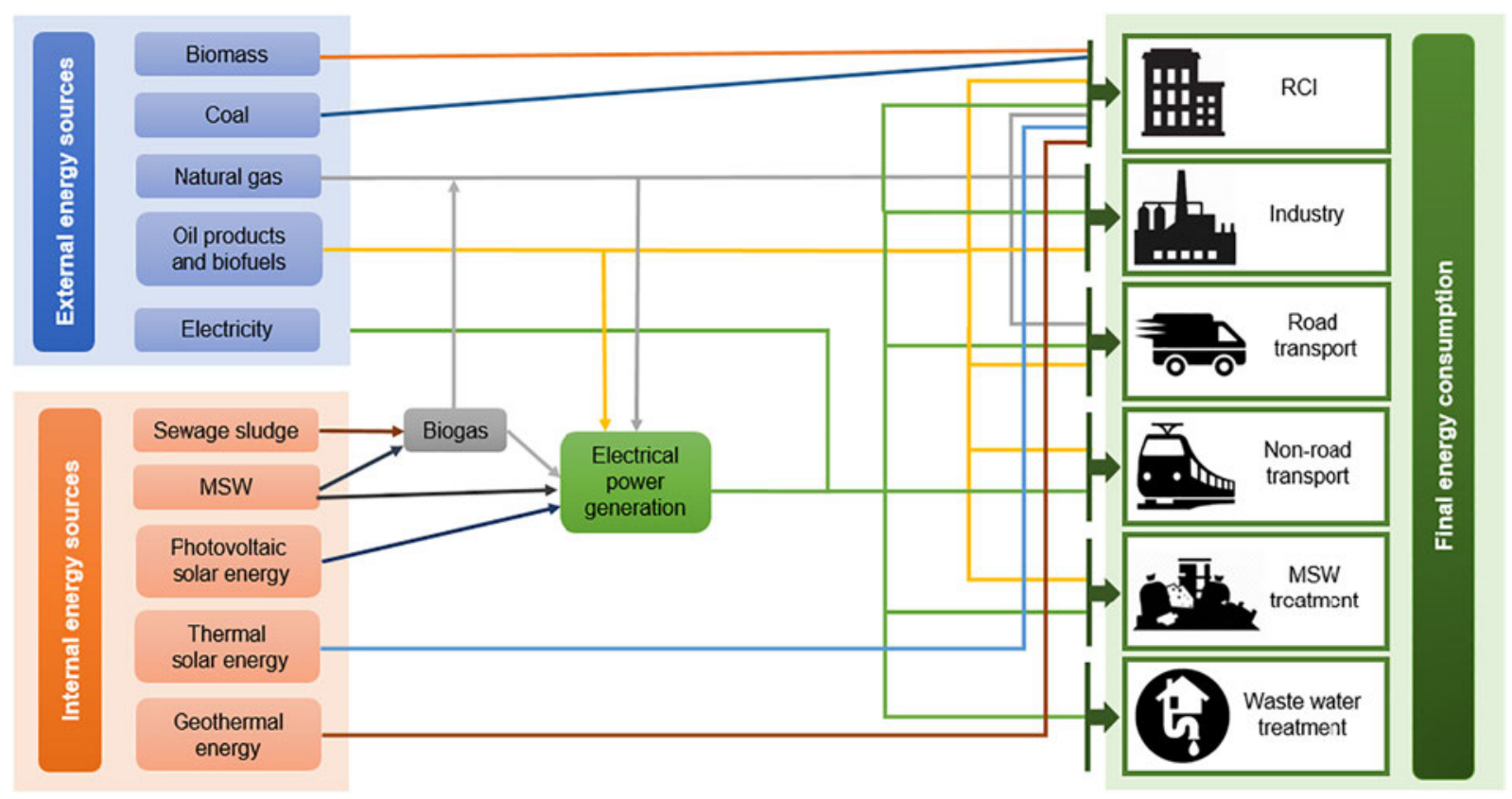

Fig. 2. Simplified flow chart of the proposed methodology for the EB of the city of Madrid.

2070:2013 of the British Standard Institution (BSI, 2013) and In ternational Organization for Standardization 37120:2018 (ISO, 2018).

Due to a lack of information, energy losses in storage and transport operations were not considered within the city boundaries. Although losses may occur in operations such as refuelling, distribution and storage of liquid, solid or gaseous fuels, as well as in electricity trans port/distribution, they were not imputed to the city since their detailed quantification depends on unavailable information, including facility characteristics and operability (AM, 2017a).
The general structure of the methodology was adapted to the case study characteristics as shown in Fig. 2.

\subsubsection{External energy sources: imports}

Energy imports represent the largest part of the final energy con sumption. The imported sources are:

- Coal and biomass, mainly consumed in the Residential Commercial Institutional (RCI) sector.

- Natural gas, directly consumed (as final energy), as fuel for elec tricity generation or as auxiliary fuel in other processes (as primary

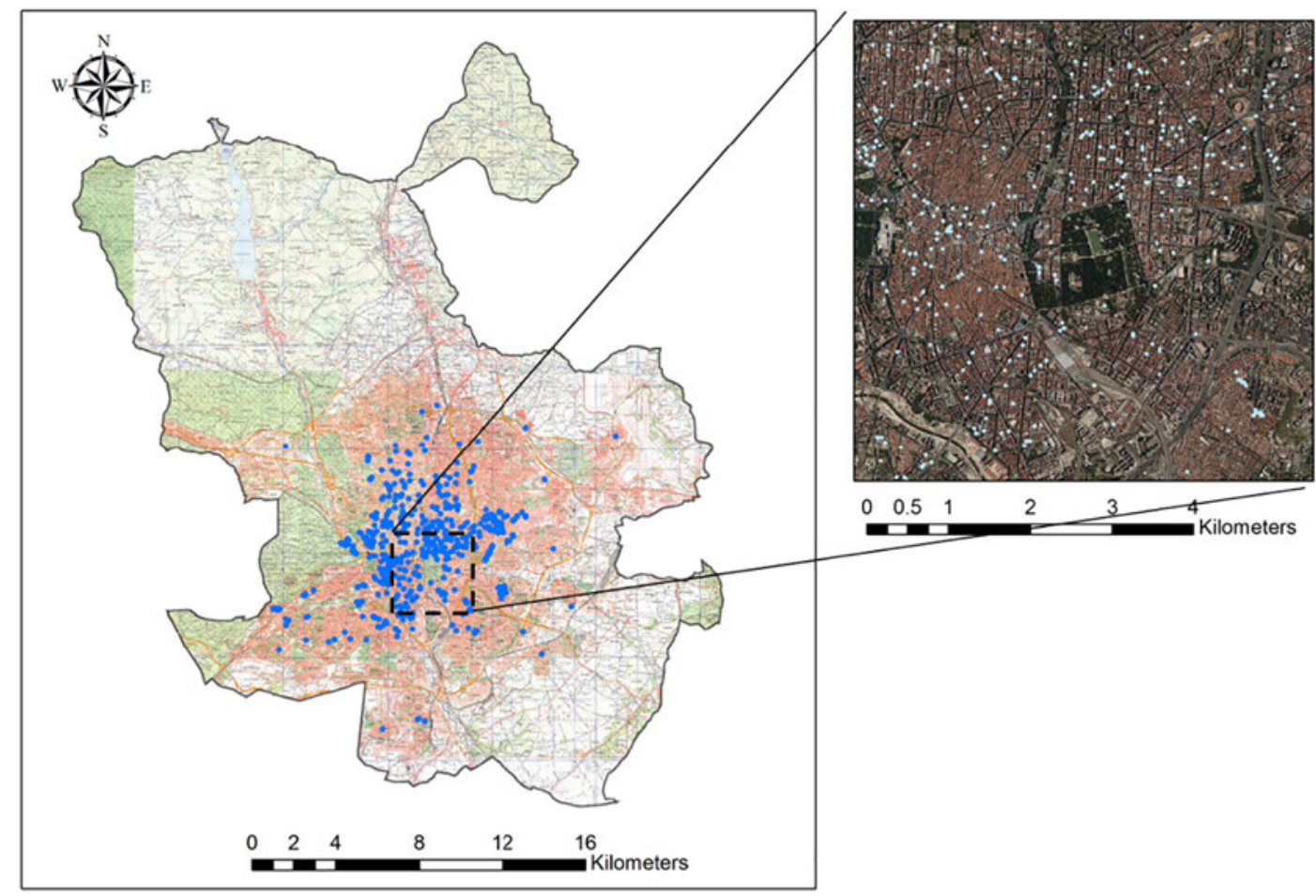

Fig. 3. Location of coal boilers in the city of Madrid (AM, 2015). 
Table 1

EB key information and its sources.

\begin{tabular}{|c|c|}
\hline Key parameters/Information & Key information sources \\
\hline & Madrid Council \\
\hline Coal, biomass and diesel boilers: location and consumption (Fig. 3 shows coal boilers example) & $\begin{array}{l}\text { Home and industrial boiler inventory (prepared and maintained by the } \\
\text { research team) (AM, 2015) }\end{array}$ \\
\hline Electricity consumption by activity & Municipal statistics. Energy (AM, 2018a) \\
\hline $\begin{array}{l}\text { Fuel consumption of MSW collection vehicle fleet, municipal buses and other municipal fleets: oil } \\
\text { products, biofuels and natural gas consumption }\end{array}$ & General Directorate of Sustainability and Environmental Control ${ }^{\mathrm{a}}$ \\
\hline Energy consumption and generation from WW treatment plants & General Directorate of Water Management $\mathrm{t}^{\mathrm{a}}$ \\
\hline Energy consumption and generation from MSW treatment plants & Parque Tecnológico de Valdemingómez (AM, 2016) \\
\hline GDP data & General Directorate of Statistics ${ }^{\mathrm{a}}$ \\
\hline Total oil products (including additives), biofuels, natural gas and biomass consumption & Commercial distributors ${ }^{\mathrm{a}}$ \\
\hline \multirow{2}{*}{$\begin{array}{l}\text { Thermal solar (square metres of panel and energy production) and geothermal (power and energy } \\
\text { production) }\end{array}$} & Madrid Regional Government \\
\hline & General Directorate of Industry and Energy ${ }^{\mathrm{a}}$ \\
\hline $\begin{array}{l}\text { Photovoltaic energy production and CHP data (when electricity for self-consumption is not } \\
\text { available, } 10 \% \text { is considered) }\end{array}$ & Spanish Regulator of Markets and Competitiveness ${ }^{a}$ \\
\hline Population & Spanish National Statistics Institute (INE, 2017) \\
\hline Aircraft operations data (number of operations by type of aircraft) & Aeropuertos Españoles y Navegación Aérea (AENA, 2017) \\
\hline \multicolumn{2}{|l|}{ Mapping between aircrafts and types of engines } \\
\hline Aircraft consumption by engine and cycle & International Civil Aviation Organization (ICAO, 2017) \\
\hline Specific consumption and/or generation data for industrial plants & Industrial plants (via questionnaires) ${ }^{\mathrm{a}}$ \\
\hline
\end{tabular}

a No public data and directly supplied.

energy to produce electricity).

- Oil products: liquefied petroleum gases (LPG), gasoline and its ad ditives (methyl tert butyl ether, MTBE, and ethyl tert butyl ether, ETBE), gasoil A (road transport), B (agricultural uses) and C (heating and industry), fuel oil and kerosene (all fuel supplied to Madrid Airports). In the case of biofuels, they can be used pure or mixed with gasoline or gasoil (bioethanol and biodiesel, respectively). When biofuels are mixed, it is necessary to know the percentage of each fraction. The percentage of MTBE and ETBE in gasoline is also needed.

The imported electricity is calculated by subtracting the total elec tricity from the grid minus the electricity generated in the city (CHP, MSW incineration, biogas use, etc.) that is reverted to the grid. The net electricity production is the difference between the gross production of each plant minus its self consumption.

\subsubsection{Internal energy sources and energy production}

The energy generation comes from the use of internal energy sources and CHP using imported energy sources (external sources):

- From internal energy sources: renewable sources and MSW valor isation. Solar (thermal and photovoltaic) and geothermal energy production plants are considered. In the MSW incineration plant (waste to energy plant), located in the Parque Tecnologico de Valdemingomez (PTV), the net electricity produced is reverted to the grid. In addition, the PTV complex has two MSW biomethani zation plants, in which one part of the biogas produced is refined and injected into the natural gas distribution network, and the other part is energetically valorised in combination with landfill biogas to produce electricity. Furthermore, the biogas generated in the anaerobic digestion of SS is used in power production for self con sumption.

- From external sources: CHP plants in the RCI sector and industry, as well as two CHP plants located in the waste water (WW) treatment plant (SS drying plants). In these CHP plants, natural gas is the most common auxiliary fuel, although others can be used. The fraction of natural gas used to generate electricity is not considered as final energy; only the fraction used with thermal applications.

\subsubsection{Final energy consumption}

It is divided into six activity sectors:
- RCI. It includes the energy consumed by the residential sector (dwellings), commercial sector (both large and small businesses) and institutional/services sector (offices, public administrations).

- Industry. It includes the final energy consumed by industrial activ ities.

- Road transport. Energy consumed by road vehicles.

- Non road transport. It includes the energy consumed by air trans port, railway and mobile machinery used in civil construction, in dustry and agriculture. The estimation of kerosene consumed by aircrafts during LTO cycles is calculated by considering the number of operations by aircraft type (AENA, 2017) and the kerosene con sumption in an LTO cycle by aircraft engine type (ICAO, 2017).

- MSW treatment. It includes the energy consumed by the activities related to MSW management, as well as LPG consumption of cre mation. Natural gas and gasoil C consumption in biogas valorisation and waste to energy plants, respectively, must not be computed as final energy because they are auxiliary fuels used in the production of electricity.

- WW treatment. It includes the activities related to WW treatment, including SS drying plants. Only the fraction of natural gas used to heat production must be computed as final energy.

\subsection{Data compilation and information sources}

The next step in calculating the EB is to identify and compile the necessary information, which is provided by either local, regional or national data sources (Table 1). When real data are not available, it is necessary to make an estimation considering the information collected in other years, provided that the historical data series are consistent.

\section{Results and discussion}

\subsection{Year 2015}

\subsubsection{Imports}

As Table 2 shows, the city is highly dependent on products $(63.2 \%)$. Electricity contributes $20.3 \%$ and natural gas $15.4 \%$. The importation of fossil sources is predominant in Madrid, although only $10 \%$ of all the kerosene imported by the airports is computed as final consumption within the city boundaries, corresponding to the fraction consumed in LTO cycles. 
Table 2

Energy imports in Madrid, 2015.

\begin{tabular}{lll}
\hline Energy source & ktoe & $\%$ \\
\hline Natural gas & 794.83 & 15.43 \\
Oil products & 3255.31 & 63.18 \\
LPG & 32.84 & 0.64 \\
Gasoline & 220.75 & 4.28 \\
Gasoil A + B & 680.95 & 13.22 \\
Gasoil C & 153.68 & 2.98 \\
Fuel oil & 0.36 & 0.01 \\
Kerosene & 2144.66 & 41.62 \\
Gasoline additives & 22.08 & 0.43 \\
Biofuels & 29.95 & 0.58 \\
Biodiesel & 29.94 & 0.58 \\
Bioethanol & 0.01 & 0.00 \\
Electricity & 1046.15 & 20.30 \\
Coal & 19.88 & 0.39 \\
Biomass & 6.51 & 0.13 \\
Total & 5152.63 & 100.00 \\
\hline
\end{tabular}

Table 3

Electrical and thermal energy generation, 2015.

\begin{tabular}{lll}
\hline Energy source & Generation & \\
\cline { 2 - 3 } & ktoe & $\%$ \\
\hline Electricity generation & 53.70 & 80.27 \\
MSW incineration & 15.27 & 22.83 \\
Biogas $^{\mathrm{a}}$ & 11.39 & 17.03 \\
Photovoltaic solar & 1.94 & 2.90 \\
CHP & 25.10 & 37.52 \\
Thermal energy & 13.21 & 19.75 \\
Thermal solar & 12.90 & 19.28 \\
Geothermal & 0.31 & 0.46 \\
Total & 66.90 & 100.00 \\
\hline
\end{tabular}

${ }^{\text {a }}$ Biogas from landfill, MSW biomethanization and anaerobic digestion of SS.

\subsubsection{Internal energy sources and energy production}

The energy generation is shown in Table 3. As mentioned in Section 3.2 , energy generation in the city ( 66.9 ktoe) was much lower than the energy imports (5152.6 ktoe; Table 2), accounting for $2.1 \%$ of final energy consumption ( $3230.5 \mathrm{ktoe}$; Table 4 ). The city of Madrid is a typical example of the urban energy behaviour in the West: it acts as an "energy sink" characterized by high energy consumption and low generation. To reduce energy dependence, this kind of city must make a greater effort in terms of energy efficiency, increasing the use of its own energy sources. Moreover, the use of its own sources provides security of supply and contributes to lower energy losses in transport operations.

CHP is the source that most contributed to energy generation (37.5\%), although MSW incineration was the greatest one among the internal energy sources $(22.8 \%)$. In this last case, electricity generation depends on the calorific value of MSW $\left(14.6 \mathrm{GJ} / \mathrm{t}_{\text {MSWincinerated }}\right)$ and the energy efficiency of the waste to energy plant (17\%).

Electrical power generation accounted for $80.3 \%$ (4.9\% of final electricity demand; 53.7 vs. 1099.8 ktoe; Table 4), whereas thermal generation was $19.8 \% .74 .2 \%$ of all the electricity produced was re verted to the grid, whereas the rest was self consumed in the generation plants.

\subsubsection{Final energy consumption}

Final energy consumption in 2015 was 3230.5 ktoe, a breakdown of which is shown in Table 4. The RCI sector was the main energy con sumer $(54.7 \%$ of the total consumption), 1768.2 ktoe: $52.8 \%$ was electricity, $35.3 \%$ natural gas and $9.7 \%$ oil products (gasoil C and LPG), the latter two used mainly for heating and hot water.

The city's central location in the Iberian Peninsula influences the extensive transport infrastructure grids that effectively interconnect the regional, national and international territory. Consequently, road transport was the second consumer in the city ( $968.8 \mathrm{ktoe})$. Within this sector, $93.2 \%$ of consumption corresponded to oil products, $3.7 \%$ to natural gas and $3.1 \%$ to biofuels.

The non road transport sector consumed $310.7 \mathrm{ktoe}$, where $71.3 \%$ were oil products $(62.6 \%$ kerosene and $8.8 \%$ gasoil B) and $28.7 \%$ was electricity. The local railway network connects the city to the outskirts using a radial structure and the underground network is the third most extensive in Europe (after London and Moscow). Regarding air trans port, the Adolfo Suárez Madrid Barajas airport is one of the busiest in Europe and the most important in Spain, with 366,608 operations in 2015 (AENA, 2017).

By contrast, the industry sector only contributed $5.2 \%$ (168.3 ktoe), with publishing and graphic arts, as well as the automotive industry, being the most relevant industrial activities (AM, 2013a). This sector has experienced a significant decrease in recent years, similarly to cities such as Berlin and Tokyo, where the industry sector consumes $<10 \%$ of the energy because economic activities have shifted from industry to services (UN HABITAT, 2008). The service sector is the main activity in the city, comprising $85.9 \%$ of local economic activity (AM, 2013a).

Finally, the WW treatment and MSW treatment sectors represented $0.3 \%$ and $0.2 \%$, respectively. In $2015,251,137,696 \mathrm{~m}^{3}$ of WW was treated in the eight treatment plants that serve Madrid (AM, 2017b). In addition, $1,200,928 \mathrm{t}$ of MSW was produced, $5.5 \%$ of Spain's MSW production (INE, 2018). The per capita MSW production rate of Madrid was $382 \mathrm{~kg} /$ inhab year, compared to $464 \mathrm{~kg} / \mathrm{inhab}$ year at the national level (INE, 2018). All MSW was sent to PTV (Pérez et al., 2018).

\subsection{Period 20062015}

\subsubsection{Imports}

Total imports decreased by $11.9 \%$ in this period (Table 5). In gen eral, the distribution of energy sources did not change significantly, although the specific contribution of natural gas decreased $(15.4 \%$ in 2015 versus $16.8 \%$ in 2006), and electricity increased. Regarding oil products, there was a downward trend (11.6\% in the whole period), except in 2015, when it increased by $4.8 \%$ compared to 2014 . One of the objectives of the municipality is to reduce oil products by $20 \%$ in

Table 4

Final energy consumption by sector and energy source (ktoe), 2015.

\begin{tabular}{|c|c|c|c|c|c|c|c|c|}
\hline Energy source & RCI & Industry & Road transport & Non-road transport & MSW treatment & WW treatment & Total & $\%$ \\
\hline Biomass & 6.51 & - & - & - & - & - & 6.51 & 0.20 \\
\hline Natural gas & 624.11 & 96.85 & 36.04 & & - & - & 756.99 & 23.43 \\
\hline Oil products & 170.57 & 9.06 & 902.76 & 221.63 & 0.12 & - & 1304.14 & 40.37 \\
\hline Biofuels & - & - & 29.95 & - & - & - & 29.95 & 0.93 \\
\hline Electricity & 933.96 & 62.37 & 0.03 & 89.05 & 4.92 & 9.51 & 1099.84 & 34.05 \\
\hline Coal & 19.88 & - & - & - & - & - & 19.88 & 0.6 \\
\hline Thermal solar & 12.90 & - & - & - & - & - & 12.90 & 0.40 \\
\hline Geothermal & 0.31 & - & - & - & - & - & 0.31 & 0.01 \\
\hline Total & 1768.24 & 168.28 & 968.77 & 310.67 & 5.05 & 9.51 & 3230.52 & 100.00 \\
\hline$\%$ & 54.74 & 5.21 & 29.99 & 9.62 & 0.16 & 0.29 & 100.00 & \\
\hline
\end{tabular}


Table 5

Energy imports in the period 2006-2015.

\begin{tabular}{|c|c|c|c|c|c|c|c|c|c|c|}
\hline \multirow[t]{2}{*}{ Year } & \multicolumn{2}{|c|}{ Natural gas } & \multicolumn{2}{|c|}{ Oil products } & \multicolumn{2}{|c|}{ Electricity } & \multicolumn{2}{|c|}{ Other sources $^{\mathrm{a}}$} & \multicolumn{2}{|l|}{ Total } \\
\hline & ktoe & $\%$ & ktoe & $\%$ & ktoe & $\%$ & ktoe & $\%$ & ktoe & $\%$ \\
\hline 2006 & 982.46 & 16.79 & 3682.91 & 62.94 & 1145.29 & 19.57 & 40.39 & 0.69 & 5851.05 & 100.00 \\
\hline 2007 & 1035.27 & 17.22 & 3744.68 & 62.29 & 1170.63 & 19.47 & 61.54 & 1.02 & 6012.12 & 100.00 \\
\hline 2008 & 1058.86 & 17.44 & 3745.28 & 61.69 & 1200.44 & 19.77 & 66.69 & 1.10 & 6071.27 & 100.00 \\
\hline 2009 & 977.18 & 16.76 & 3566.35 & 61.17 & 1185.96 & 20.34 & 100.56 & 1.72 & 5830.05 & 100.00 \\
\hline 2010 & 897.89 & 15.64 & 3567.13 & 62.13 & 1168.96 & 20.36 & 106.98 & 1.86 & 5740.96 & 100.00 \\
\hline 2011 & 814.46 & 14.53 & 3554.17 & 63.40 & 1130.39 & 20.16 & 107.26 & 1.91 & 5606.28 & 100.00 \\
\hline 2012 & 927.67 & 17.00 & 3317.89 & 60.81 & 1108.72 & 20.32 & 101.48 & 1.86 & 5455.76 & 100.00 \\
\hline 2013 & 942.58 & 18.39 & 3069.00 & 59.88 & 1058.37 & 20.65 & 55.45 & 1.08 & 5125.40 & 100.00 \\
\hline 2014 & 813.09 & 16.20 & 3106.72 & 61.91 & 1041.01 & 20.74 & 57.56 & 1.15 & 5018.39 & 100.00 \\
\hline 2015 & 794.83 & 15.43 & 3255.31 & 63.18 & 1046.15 & 20.30 & 56.34 & 1.09 & 5152.63 & 100.00 \\
\hline \% change 2006-2015 & & 19.10 & & 11.61 & & $8.66 \%$ & & 39.47 & & 11.94 \\
\hline
\end{tabular}

a Including biofuels, biomass, coal and hydrogen.

2020 with respect to 2011, excluding kerosene (AM, 2014). In 2015, the reduction was $6.9 \%$.

\subsubsection{Internal energy sources and energy production}

Energy generation decreased by $5.3 \%$ in this period (Fig. 4). The sharp reduction since 2014 was due to the closure of two SS drying plants. However, CHP still accounted for $37.5 \%$ of total energy gen eration in 2015. The electricity generation in MSW incineration de creased by $17.8 \%$ due to the fluctuation in the quantity and composi tion of incinerated MSW. Furthermore, energy generation from biogas valorisation decreased by $20.3 \%$, because of falling biogas extraction at the closed landfill in PTV. The landfill currently in use does not produce significant amounts of biogas.

On the other hand, solar (photovoltaic and thermal) energy gradu ally increased its contribution to the total generation, totalling $22.2 \%$ in 2015 versus $3.3 \%$ in 2006. Geothermal energy is still in an emergent stage $(0.3 \%)$, although an effort is being made to study the viability of this technology in more locations. Electrical power generation ac counted for $4.87 .6 \%$ of the total electricity consumed in the period. An objective of the municipal energy plan (AM, 2014) is to self generate $10 \%$ of the final energy demand in 2020 . However, this value stood at $2.1 \%$ in 2015 . This plan seeks to promote the development of high efficient district heating and cooling systems, the integration of re newable generation systems in new and existing buildings, and the improvement of MSW valorisation.

\subsubsection{Final energy consumption}

This parameter went down by $16.1 \%$ in the period evaluated
(3852.7 to $3230.6 \mathrm{ktoe}$ ) (Fig. 5.). This decrease is due to the combi nation of two factors: i) saving and energy efficiency policies im plemented by the local government and ii) the effect of the economic crisis that Spain suffered starting in 2008.

Oil products were the main energy source ( $40.4 \%$ in 2015 ), al though in 2006 their contribution was $43.3 \%$. Natural gas consumption decreased by $18.3 \%$ since 2006 , although the gas supply network in operation experienced an increment of $35.1 \%$ (4427 km in 2015), de noting a more efficient use (AM, 2018b).

Coal consumption experienced a gradual decrease in RCI heating due to its substitution by natural gas, leading to a $48.6 \%$ reduction since 2006 (contribution of $0.5 \%$ in 2015). In addition, biofuels decreased substantially from 2012 to 2013 due to the municipal bus fleet's shift away from biodiesel.

The RCI sector accounted for $54.7 \%$ of final energy consumption in 2015 , followed by road transport with $30 \%$. However, both cases saw a decrease in consumption of $10.2 \%$ and $14.9 \%$ compared to 2006 , re spectively. The industry sector has a cumulative decrease of $46.6 \%$ (Fig. 6).

Consequently, the planned energy saving and efficiency measures targeted the sectors that demand the most energy resources in the city: $\mathrm{RCI}$ and road transport. Regarding the RCI sector, the local objective is to reduce final energy consumption by $10 \%$ in 2020 with respect to 2011 (AM, 2014): a reduction of $3.1 \%$ was achieved in 2015. Other measures in the sector are the rehabilitation of existing buildings, the promotion of energy efficient new constructions and control and management in municipal buildings and infrastructures through energy service companies. One of the investments for reducing electricity

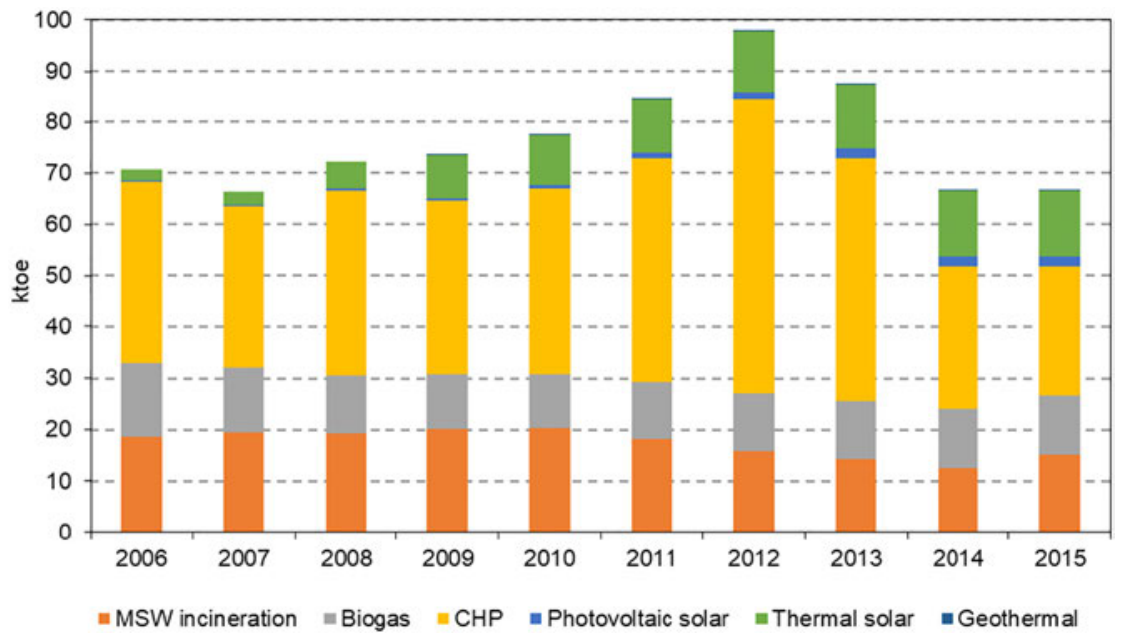

Fig. 4. Energy generation by source (2006-2015). 


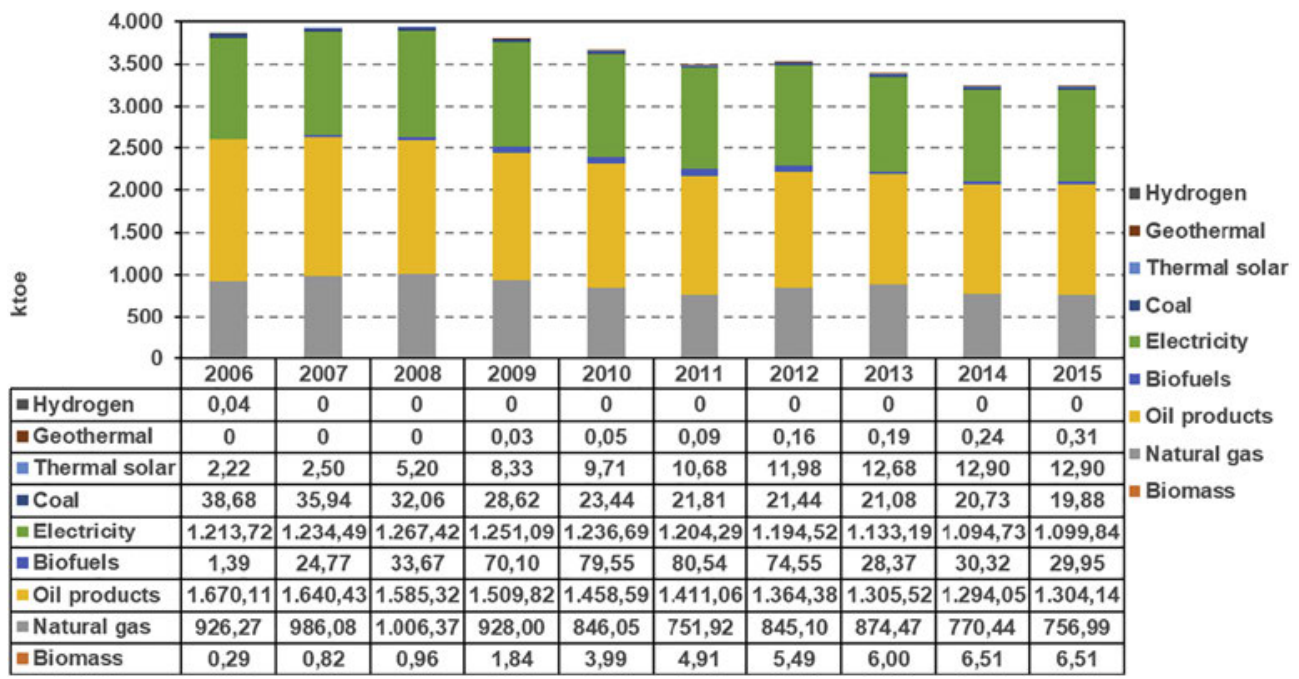

Fig. 5. Final energy consumption by source (2006-2015).

consumption was the replacement of 225,000 public lighting points with more efficient systems between 2014 and 2015, 85,000 of them with LED technology (AM, 2013b). Consequently, public lighting con sumption decreased by $38.4 \%$ in 2015 compared to 2011 (reducing the contribution to final electricity consumption from $1.0 \%$ to $0.7 \%$ ).

Regarding the road transport sector, the 2020 objective is to reduce GHG emissions by $20 \%$ with respect to 2011 (AM, 2014): a reduction of $3.6 \%$ was achieved in 2015. The most relevant measures were the promotion of distribution and supply infrastructure for alternative en ergy sources (natural gas, LPG and electricity); the reduction of energy consumption in public fleets and private vehicles; and the promotion of alternative transport modes (public transport, car sharing and bicycle).

\subsubsection{Energy indicators}

Per capita consumption was 1.03 toe/inhabitant in 2015 (43.05 GJ/ inhabitant). It is a low value compared to other cities like New York, Beijing, Paris, Berlin, London, Rome, Tokyo or Lisbon, whose per capita consumption, according to Schulz (2010), ranges from 128.07 (New York) to $48.65 \mathrm{GJ} /$ inhabitant (Lisbon). It decreased by $16.5 \%$ in the period 2006 2015, even though the population grew by 0.4\% (Fig. 7). The decrease in final energy consumption also led to a decrease in energy intensity of $18.8 \%$ (33.92 toe/M€ in 2015), whereas the GDP rose by $3.2 \%$. Regarding final energy intensity, the $2020 \mathrm{EU}$ objective is to achieve a $20 \%$ reduction with respect to 2011 (which is supported by the municipal action plan) (AM, 2014). In 2015, the decrease was 7\% compared to 2011 , thus requiring an additional $13 \%$ reduction of $(2.6 \%$ per year) to achieve the 2020 commitment. The average reduction in 20112015 was 1.7\% per year, so a greater effort is required.

A comparison with the national situation is included in Appendix A.

\subsection{Reviewing/updating the $E B$}

As a basic and critical point of the methodology, the whole histor ical series must be reviewed annually with the aim of updating the information, as well as checking for improvements and possible new data sources. This process is essential to consistently track compliance with the measures implemented during the period in question.

In order to illustrate the ten year process, the variation in final consumption in the first version of 2006 and the last version carried out for that year (in the $2015 \mathrm{~EB}$, which includes the period 2006 2015) is shown in Table 6, yielding a change in final energy consumption of $4.4 \%$.

The $7.5 \%$ increase in oil products is caused by different modifica tions: the inclusion of distributor data instead of estimating it (for LPG), specific information from individual plants (fuel oil, gasoil C), im proved data quality in estimating the LTO cycles and the inclusion of boiler inventory data (gasoil C). Its inclusion, along with updated in formation, also modified the consumption of biomass and coal. Natural

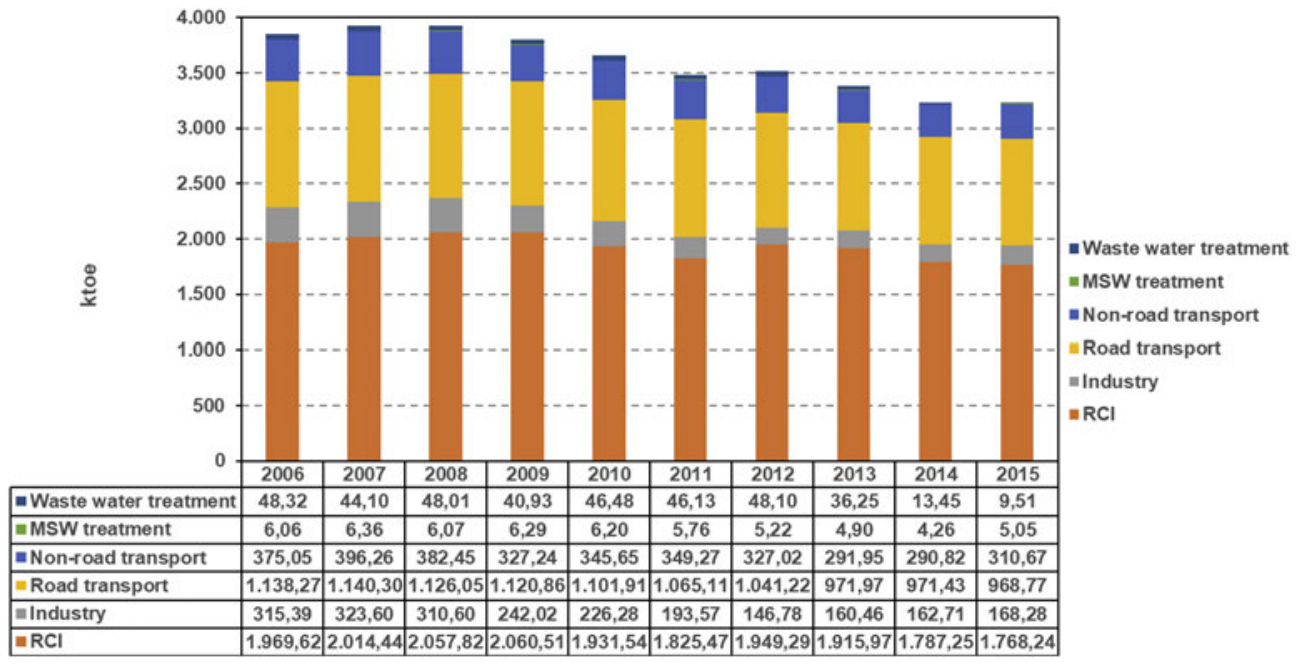

Fig. 6. Final energy consumption by sector (2006-2015). 


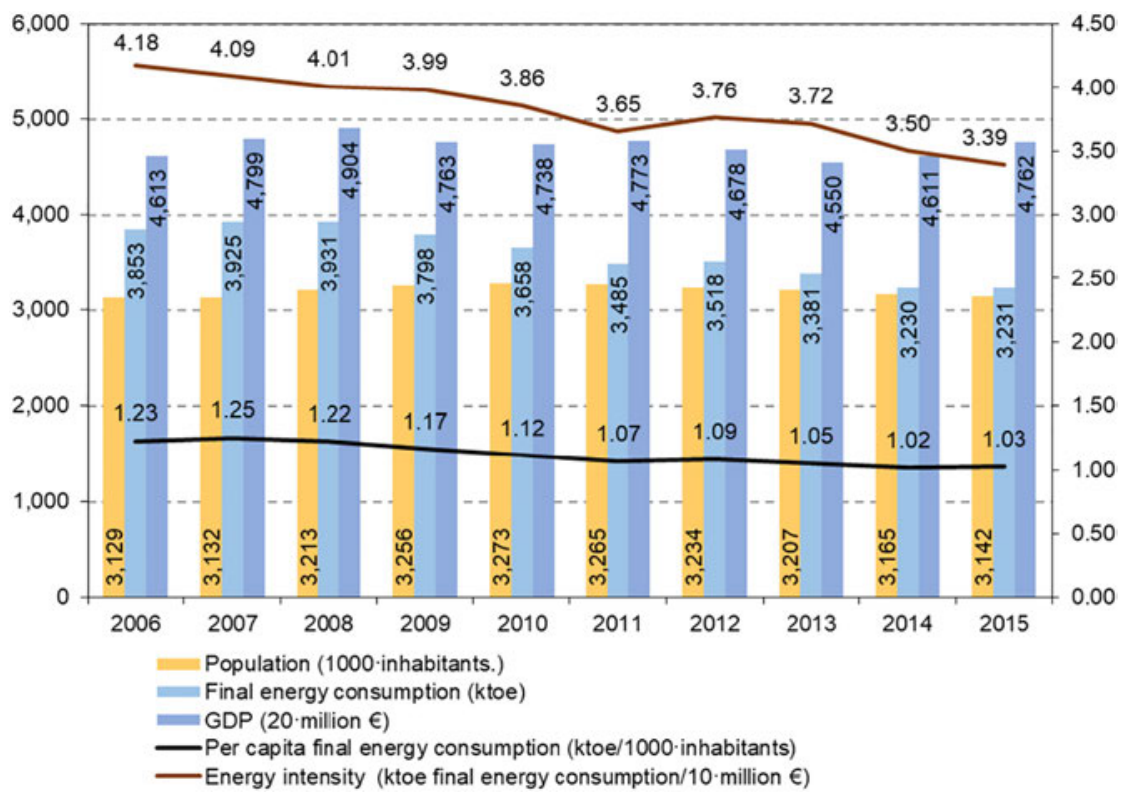

Fig. 7. Evolution of energy indicators (2006-2015).

Table 6

Differences in final energy consumption: year 2006 in the first and the last edition of EB.

\begin{tabular}{lllc}
\hline Final consumption & $2006(2006 \mathrm{~EB})$ & $2006(2015 \mathrm{~EB})$ & $\%$ \\
\hline Biomass & 0.30 & 0.29 & 4.5 \\
Natural gas & 890.53 & 926.27 & 4.0 \\
Oil products & 1553.87 & 1670.11 & 7.5 \\
Biofuels & 1.40 & 1.39 & 1.0 \\
Electricity & 1213.81 & 1213.72 & 0.0 \\
Coal & 28.44 & 38.68 & 36.0 \\
Thermal solar & 2.22 & 2.22 & 0.0 \\
Geothermal & 0.00 & 0.00 & - \\
Hydrogen & 0.00 & 0.04 & - \\
Total & 3690.56 & 3852.72 & 4.4 \\
\hline
\end{tabular}

gas has increased $4.0 \%$ due to various changes, among which are the inclusion of the consumption by the MSW collection fleet, the use of data from commercial distributors instead of municipal statistics and the inclusion of specific consumptions by industrial plants.

\subsection{Applications}

The EB is a key instrument for preparing GHG and Air Pollutant Emission Inventories (AM, 2018c), as well as for developing AQ and CC plans (AM, 2017c, 2014; Borge et al., 2014; Vedrenne et al., 2016).

The emissions inventory relies on the EMEP/EEA methodology, which is coordinated by the European Environment Agency (EEA, 2016) and meets the requirements established by the Intergovernmental Panel on CC (IPCC, 2006). It includes an estimation for acidifying gases, ozone precursors, particulate matter and GHG emissions. In turn, GHG emissions are disaggregated in direct emissions (within the city boundaries, scope 1 emissions as per BSI (2013, 2011) and WRI (2014)), and indirect emissions of electricity consumption (scope 2, emissions as per BSI $(2013,2011)$ and WRI (2014)) and losses in transport (scope 3, emissions as per BSI $(2013,2011)$ and WRI (2014)).

The evolution of both final energy consumption and total GHG emissions by sector is shown in Fig. 8. Note the close relationship be tween them, which is why constant feedback is needed (it is important to realize that not all GHG emissions are related to energy use). In 2015 GHG emissions were 11,232 t CO $_{2}$ eq (AM, 2018c), a $27.9 \%$ decrease since 2006 (the decrease in energy consumption was $16.1 \%$ ). The rate of emissions per capita decreased by $28.2 \%$ ( $3.6 \mathrm{t} \mathrm{CO}_{2}$ eq/inhabitant) and the emissions intensity per unit of GDP fell $30.2 \%\left(118 \mathrm{t} \mathrm{CO}_{2} \mathrm{eq} / \mathrm{M}\right.$ $€$ in 2015).

In the last ten years, the EB has been a useful tool for decision making regarding environmental policy, as well as an essential element for gaining a basic understanding of the activities affecting AQ, sus tainable energy management and CC mitigation. It provides, in con junction with the GHG and air pollution emission inventory, critical information to develop, implement and track policy initiatives and action plans at the municipal level (AM, 2017c, 2014).

In 2008, Madrid joined the Covenant of Mayors for Climate and Energy (COM), a European initiative that brings together thousands of local governments voluntarily committed to improving energy effi ciency and using renewable energy sources with the aim to comply with EU climate, energy and AQ objectives (Monforti Ferrario et al., 2018). The signatory cities of the COM are required to submit a Baseline Emission Inventory and a Sustainable Energy and Climate Action Plan (SECAP) (COM, 2016), for which the EB is a crucial input.

\section{Conclusions}

This manuscript presents a structured methodology for preparing an $\mathrm{EB}$, beyond the annual statistics published by different government agencies and energy companies. This methodology yields detailed knowledge of the energy generated and consumed in a city (by energy source and use), compared to the use of aggregated regional or national EB. Moreover, the development and annual revision of data manage ment and collection procedures allow optimizing the continuous im provement process, as well as the representativeness and quality of the data.

During its ten year application to the city of Madrid, the EB has been essential to preparing a consistent GHG and air pollution emis sions inventory. Together, these tools provided strategic information to the City Council, facilitating the policy making process and allowing it to properly plan and implement measures related to energy saving and energy efficiency, in order to mitigate CC and improve AQ.

Through its energy and CC plan, the city of Madrid set a group of objectives for 2020 in terms of reducing final energy consumption (saving and energy efficiency), increasing internal energy generation (reduced dependence on external energy, improved level of self 


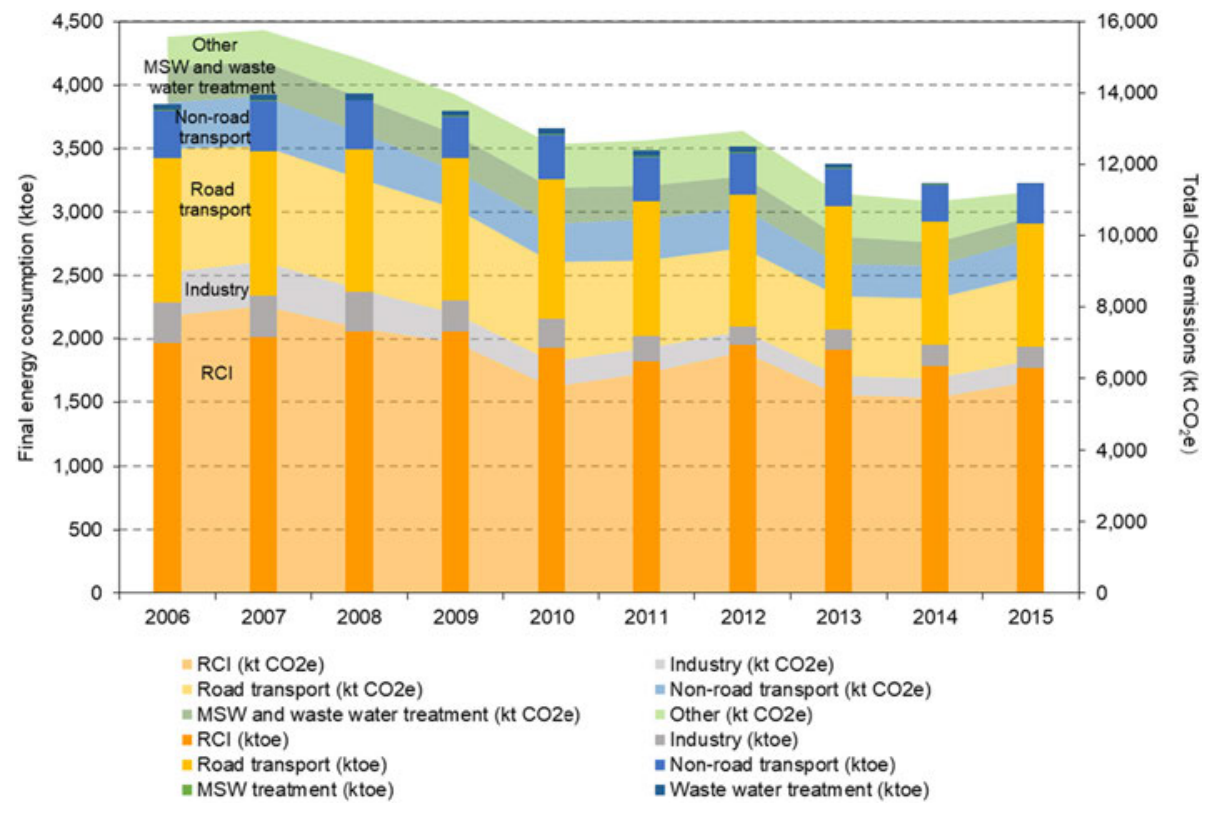

Fig. 8. Final energy consumption and GHG emissions by sector (2006-2015).

sufficiency and security of supply) and increasing renewable energy use. The balance showed that, in order to reach these objectives, the city of Madrid should eliminate coal consumption in the RCI sector, as well as increase its energy efficiency. Therefore, the EB showed that an effort to improve insulation and heat and hot water systems in buildings was necessary. Regarding road transport, the EB illustrated the need to further promote public transport, as well as to develop more efficient and environmentally friendly alternative energy sources.

This methodology is an easy to implement tool that could be ap plied to other cities (e.g. cities along the world which have not yet developed an EB).

Some limitations were found during this study. The first one in volves the lack of specific information on the energy distribution losses within city boundaries (electricity and fuels). The research team is working on this for upcoming editions. Another limitation is related to aircraft fuel consumption and the differences between the methodology considered in this study and others, such as WRI (2014), BSI (2013) and ISO (2018). In future studies the research team will carry out a comparison between methodologies. Another limitation involves the arduousness of collecting the vast amount of data needed at the city level. However, some specific data could be assumed using average values.

Finally, the one and half year lag in the study (necessary to collect the required information) delays an immediate assessment of the effect of the measures implemented in the EB. Despite this, the EB is a strong monitoring tool for assessing the application of improving measures and for evaluating the degree of compliance with the city's energy objectives.

\section{Acknowledgments}

This work was done as part of the project entitled Elaboración y Actualización del Inventario de Emisiones Contaminantes a la Atmósfera y del Balance Energético del Término Municipal de Madrid (reference number 300/2012/00489), granted by the Madrid City Council.

\section{Appendix A. Comparison with national situation}

In 2015, the main final energy source consumed in Madrid was oil products, accounting for $40.4 \%$ of all consumption, although this figure was higher $(52.7 \%)$ at the national level (Table A1). The contributions of electricity and natural gas were $34.1 \%$ and $23.4 \%$, higher than in Spain as a whole ( $22.8 \%$ and $16.9 \%$, respectively). At the sector level, the RCI and transport sectors were the main consumers in Madrid, with a contribution of $54.7 \%$ and $39.6 \%$, whereas in Spain these sectors accounted for $34.8 \%$ and $41.6 \%$, respectively. The greatest difference lies in the industry sector, since the contribution in Madrid was considerably lower than in the rest of Spain (5.7\% versus 23.5\%). This is because the energy consumption structure in Madrid is based on the services sector, which is less energetically intensive than industry.

Madrid covers $0.1 \%$ of the national surface, but has $6.7 \%$ of the total population. Per capita consumption in Madrid was $45.4 \%$ lower than in the rest of Spain (1.03 versus 1.88 toe/inhabitant), among other reasons, because of the lack of heavy industry. Energy intensity was also lower in Madrid (33.9 versus 107.4 toe/million $€$ ).

Table A1

Final energy consumption of Madrid and Spain, 2015.

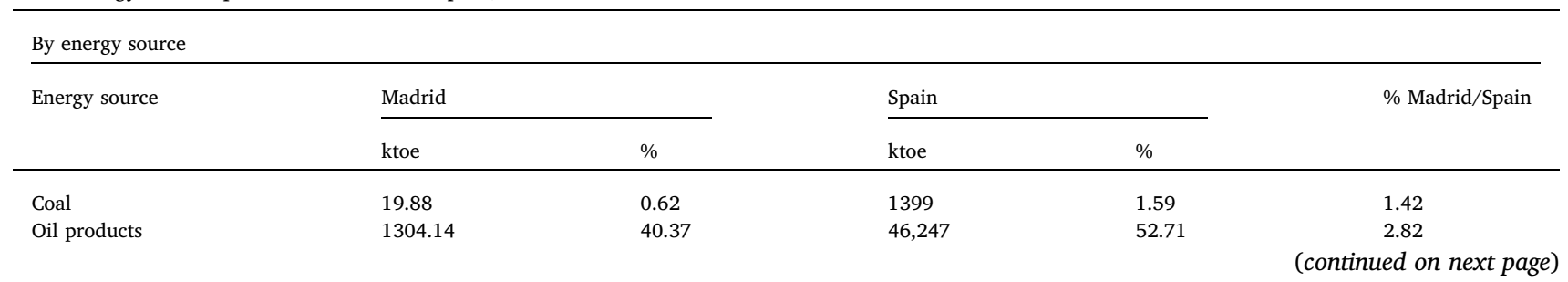


Table A1 (continued)

\begin{tabular}{|c|c|c|c|c|c|}
\hline \multicolumn{6}{|l|}{ By energy source } \\
\hline \multirow[t]{2}{*}{ Energy source } & \multicolumn{2}{|l|}{ Madrid } & \multicolumn{2}{|l|}{ Spain } & \multirow[t]{2}{*}{ \% Madrid/Spain } \\
\hline & ktoe & $\%$ & ktoe & $\%$ & \\
\hline Natural gas & 756.99 & 23.43 & 14,792 & 16.86 & 5.12 \\
\hline Electricity & 1099.84 & 34.05 & 19,999 & 22.79 & 5.50 \\
\hline Renewable energy & 49.66 & 1.54 & 5302 & 6.04 & 0.94 \\
\hline Total & 3230.52 & 100.00 & 87,739 & 100.00 & 3.68 \\
\hline \multicolumn{6}{|l|}{ By sector } \\
\hline \multirow[t]{2}{*}{ Final sector } & Madrid & Spain & Madrid & Spain & \multirow[t]{2}{*}{ \% Madrid/Spain } \\
\hline & ktoe & $\%$ & ktoe & $\%$ & \\
\hline $\mathrm{RCI}$ & 1768.24 & 54.74 & 30,550 & 34.82 & 5.79 \\
\hline Transport & 1279.45 & 39.61 & 36,542 & 41.65 & 3.50 \\
\hline Industry & 182.83 & 5.66 & 20,647 & 23.53 & 0.89 \\
\hline \multicolumn{6}{|l|}{ Energy indicators } \\
\hline \multicolumn{2}{|l|}{ Parameter } & Madrid & \multicolumn{2}{|r|}{ Spain } & \% Madrid/Spain \\
\hline \multicolumn{2}{|l|}{ Surface $\left(\mathrm{km}^{2}\right)$} & 606 & \multicolumn{2}{|r|}{505,990} & 0.12 \\
\hline \multicolumn{2}{|c|}{ Population (inhabitants) } & \multicolumn{2}{|l|}{$3,141,991$} & $46,624,382$ & 6.74 \\
\hline \multicolumn{2}{|l|}{ GDP (M€) } & 95,236 & \multicolumn{2}{|r|}{816,971} & 11.66 \\
\hline \multicolumn{2}{|c|}{ Energy intensity (toe/M€) } & 33.92 & \multicolumn{2}{|r|}{107.40} & - \\
\hline \multicolumn{2}{|c|}{ Per capita consumption (toe/inhabitant) } & 1.03 & \multicolumn{2}{|r|}{1.88} & - \\
\hline
\end{tabular}

Regarding the evolution of energy indicators in the period 20062015 (Fig. A1), we see that per capita consumption in Madrid decreased by $16.5 \%$, due to a $16.1 \%$ decrease in final energy consumption and a $0.4 \%$ increase in population. Nationally, the decrease was $18.4 \%$. Energy intensity in Madrid decreased by $18.8 \%$ (20\% nationally) as a consequence of the trend in final energy consumption, and the $3.2 \%$ increase in GDP.

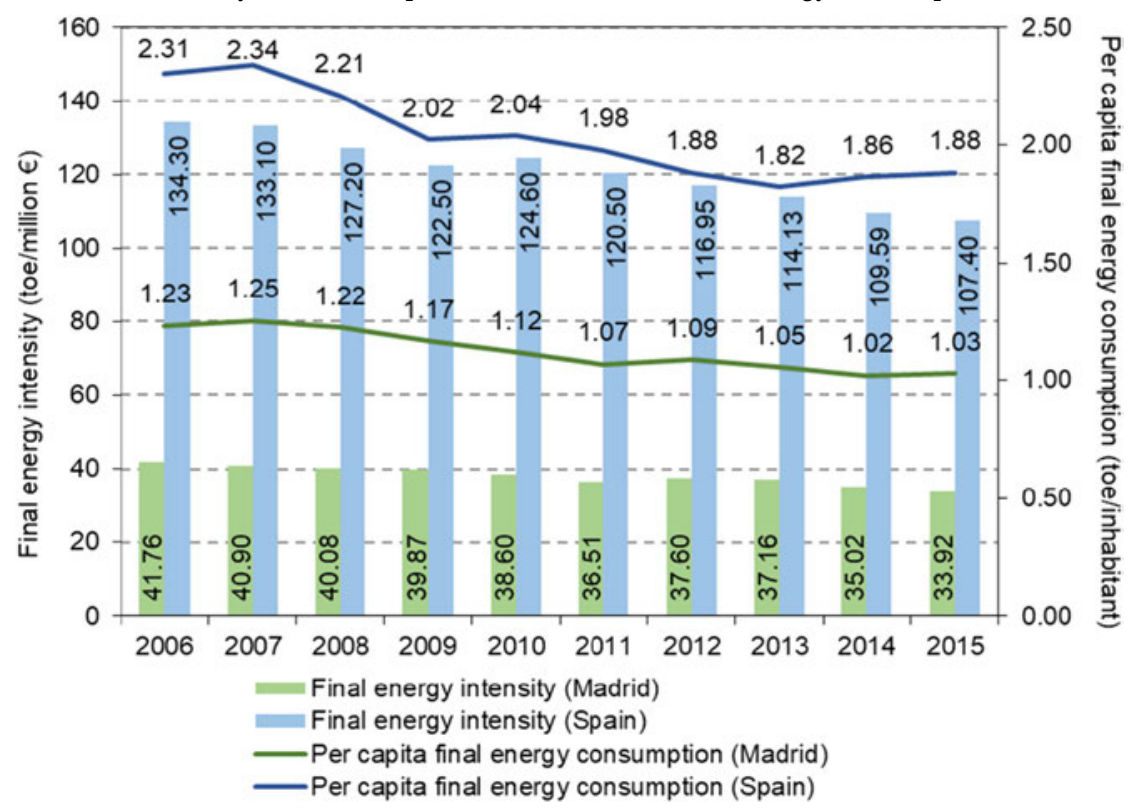

Fig. A1. Evolution of energy indicators for Madrid and Spain (2006-2015).

\section{References}

Aeropuertos Españoles y Navegación Aérea (AENA), 2017. Estadísticas de tráfico aéreo http://www.aena.es/csee/Satellite? $\mathrm{c}=$ Page\&cid $=1113582476715 \&$ pagename $=$ Estadisticas\%2FEstadisticas.

Ayuntamiento de Madrid (AM) (2013a). Estructura económica de la ciudad de Madrid. Análisis socioeconómico978-84-7812-763-4.

Ayuntamiento de Madrid (AM), 2013b. Gestión integral y Energética de instalaciones urbanas de la Ciudad de Madrid. https://sede.madrid.es/sites/v/index.jsp? vgnextoid = a2f7909e42ae1410VgnVCM2000000c205a0aRCRD\&vgnextchannel = 8afd814231 ede410VgnVCM1000000b205a0aRCRD.

Ayuntamiento de Madrid (AM), 2014. Plan de Uso Sostenible de la Energía y Prevención del Cambio Climático de la ciudad de Madrid, horizonte 2020. http://www.madrid. es/UnidadesDescentralizadas/Sostenibilidad/EspeInf/EnergiayCC/02PECCH/ Ficheros/PECCH2020.pdf.

Ayuntamiento de Madrid (AM), 2015. Censo de calderas que consumen combustibles singulares. Biomasa, carbón y gasóleo. Años 2014 y 2015. Área de Gobierno de Medio Ambiente y Movilidad. http://www.madrid.es/UnidadesDescentralizadas/ Sostenibilidad/EspeInf/EnergiayCC/03Energia/3cEdificios/3c05Calderas/Ficheros/ 
CensoCalderaMad2015.pdf.

Ayuntamiento de Madrid (AM), 2016. Memoria de actividades del Parque Tecnológico de Valdemingómez, 2015. Dirección General del Parque Tecnológico de Valdemingómez. http://www.madrid.mobi/UnidadesDescentralizadas/ Valdemingomez/Publicaciones/Memoria PTV 2015.pdf.

Ayuntamiento de Madrid (AM), 2017a. Balance Energético del municipio de Madrid, año 2015. Área de Gobierno de Medio ambiente y Movilidad. http://www.madrid.es/ UnidadesDescentralizadas/Sostenibilidad/EspeInf/EnergiayCC/03Energia/ 3aBalance/Ficheros/BalanceEnergMadrid2015.pdf.

Ayuntamiento de Madrid (AM), 2017b. Áreas de información estadística: Estaciones de puradoras, características generales. http://www2.munimadrid.es/CSE6/control/ seleccionDatos? numSerie $=14030300022$

Ayuntamiento de Madrid (AM), 2017c. Air quality and climate change action plan of Madrid City: Plan A. http://www.madrid.es/portales/munimadrid/es/Inicio/Medio ambiente/Publicaciones/Plan-de-Calidad-de-aire-de-la-ciudad-de-Madrid-y-CambioClimatico-PLAN-A-?vgnextfmt $=$ default\&vgnextoid $=$ 2b809df12834b510VgnVCM1000001d4a900aRCRD\&vgnextchannel = f6ff79ed268fe410VgnVCM1000000b205a0aRCRD.

Ayuntamiento de Madrid (AM), 2018a. Áreas de información estadística. Energía: Gas y Electricidad. Electricidad facturada en la Ciudad de Madrid por Actividad principal. http://www-2.munimadrid.es/CSE6/control/seleccionDatos?numSerie = 8010100030 .

Ayuntamiento de Madrid (AM), 2018b. Áreas de información estadística. Energía: Gas y Electricidad. Red de gas en servicio en la Ciudad de Madrid por Años. http://www-2. munimadrid.es/CSE6/control/menuCSE.

Ayuntamiento de Madrid (AM), 2018c. Inventario de emisiones de contaminantes a la atmósfera en la Ciudad de Madrid 1999-2015. Área de Gobierno de Medio Ambiente y Movilidad. http://www.madrid.es/UnidadesDescentralizadas/Sostenibilidad/ EspeInf/EnergiayCC/04CambioClimatico/4aInventario/Ficheros/ InventarioEAM2015.pdf.

Baynes, T., Lenzen, M., Steinberger, J. K., \& Bai, X. (2011). Comparison of household consumption and regional production approaches to assess urban energy use and implications for policy. Energy Policy, 39, 7298-7309.

Bhattacharyya, S. C. (2011). Chapter 2: Energy data and energy balance. Energy economics. Concept, issues, markets and governance. London: Springer-Verlag.

Borge, R., Lumbreras, L., Pérez, J., de la Paz, D., Vedrenne, M., de Andrés, J. M., \& Rodríguez, M. E. (2014). Emission inventories and modelling requirements for the development of air quality plans. Application to Madrid (Spain). Science of the Total Environment, 466-467, 809-819.

British Standards Institution (BSI) (2011). PAS 2050: 2011 specification for the assessment of the life cycle greenhouse gas emissions of goods and services. BSI Standards Limited2011.

British Standards Institution (BSI) (2013). PAS 2070: 2013 specification for the assessment of greenhouse gas emissions of a city direct plus supply chain and consumption-based methodologies. BSI Standards Limited2013.

Cai, Z., Ou, X., Zhang, X., Zhang, X., He, J., \& Xing, Y. (2013). Comparative study of energy consumption and $\mathrm{CO}_{2}$ emissions between Beijing and London. Frontiers in Energy, 7, 1-5.

Covenant of Mayors (COM), 2016. Covenant of Mayors for climate and energy: Commitment document. https://www.covenantofmayors.eu/support/library.html.

Covenant of Mayors (COM) (2018). Reducing energy dependence in European cities. Cofunded by the intelligent energy Europe program of the European Union. Covenant of Mayorshttps://www.covenantofmayors.eu/IMG/pdf/CoM Reducing Energy Dependence for web.pdf.

Dent, C. M., Bale, C., Wadud, Z., \& Voss, H. (2016). Cities, energy and climate change mitigation: An introduction. Cities, 54, 1-3.

European Commission (EC), 2008. COM (2008) 772. Energy 2020: Energy efficiency: Delivering the $20 \%$ target. Communication from the Commission. https://eur-lex. europa.eu/legal-content/EN/TXT/?uri = celex:52008DC0772.

European Commission (EC), 2010. COM (2010) 639. Energy 2020: A strategy for competitive, sustainable and secure energy. Communication from the Commission to the European Parliament, the Council, the European Economic and Social Committee and the Committee of the Regions. https://eur-lex.europa.eu/legal-content/EN/TXT/? uri $=$ celex:52010DC0639.

European Environmental Agency (EEA) (2016). EMEP/EEA air pollutant emission inventory guidebook, 2016. EEA report no. 21/2016European Environmental Agencyhttps://www.eea.europa.eu/publications/emep-eea-guidebook-2016.

Fichera, A., Inturri, G., La Greca, P., \& Palermo, V. (2016). A model for mapping the energy consumption of buildings, transport and outdoor lighting of neighbourhoods. Cities, 55, 49-60.

Gómez-Ceballos, D. J., \& Morán-Perafá, R. G. (2015). Análisis energético urbano usando metodologías de gestión integral de energía: Un caso de estudio en la ciudad de Pasto. Energética, 45.

Haarstad, H. (2016). Where are urban energy transitions governed? Conceptualizing the complex governance arrangements for low-carbon mobility in Europe. Cities, 54, 4-10.

Holden, E., \& Norland, I. T. (2005). Three challenges for the compact city as a sustainable urban form: Household consumption of energy and transport in eight residential areas in the greater Oslo region. Urban Studies, 42, 2145-2166.

Howard, B., Parshall, L., Thompson, J., Hammer, S., Dickinson, J., \& Modi, V. (2012). Spatial distribution of urban building energy consumption by end use. Energy and
Buildings, 45, 141-151.

Instituto Nacional de Estadística (INE), 2017. Cifras oficiales de población resultantes de la revisión del Padrón municipal a 1 de enero. Detalle municipal. http://www.ine.es/ jaxiT3/Datos.htm?t = 2881 .

Instituto Nacional de Estadística (INE), 2018. Estadísticas sobre recogida y tratamiento de residuos. Residuos Urbanos. http://www.ine.es/jaxi/Tabla.htm?path $=/ \mathrm{t} 26 / \mathrm{e} 068$ / p01/serie/10/\&file $=02003$.px\&L $=0$.

Intergovernmental Panel on Climate Change (IPCC), 2006. 2006 IPCC Guidelines for National Greenhouse Gas Inventories. http://www.ipcc-nggip.iges.or.jp/public/ 2006gl/spanish/index.html.

International Civil Aviation Organization (ICAO), 2017. Aircraft Engine Emissions Databank, 05/02/2016 version. https://www.easa.europa.eu/document-library/ icao-aircraft-engine-emissions-databank.

International Energy Agency (IEA) (2016). Energy technology perspectives 2016. Towards sustainable urban energy systems.

International Energy Agency (IEA) (2017). Energy technology perspectives 2017. Catalysing energy technology transformations.

International Organization for Standardization (ISO), 2018. Sustainable cities and communities - Indicators for city services and quality of life. (ISO 37120:2018).

Liu, M., Huang, Y., Jin, Z., Liu, X., Bi, J., \& Jantunen, M. J. (2017). Estimating health cobenefits of greenhouse gas reduction strategies with a simplified energy balance based model: The Suzhou City case. Journal of Cleaner Production, 142, 3332-3342.

Ministerio de Energía, Turismo y Agenda Digital (MINETAD), 2018. Estadísticas y Balances energéticos. http://www.minetad.gob.es/energia/balances/Paginas/Index. aspx.

Moghadam, S. T., Toniolo, J., Mutani, G., \& Lombardi, P. (2018). A GIS-statistical approach for assessing built environment energy use at urban scale. Sustainable Cities and Society, 37, 70-84.

Monforti-Ferrario, F., Kona, A., Peduzzi, E., Pernigotti, D., \& Pisoni, E. (2018). The impact on air quality of energy saving measures in the major cities signatories of the Covenant of Mayors initiative. Environment International, 118, 222-234.

Niu, S., Zhang, X., Zhao, C., Ding, Y., Niu, Y., \& Christensen, T. H. (2011). Household energy use and emission reduction effects of energy conversion in Lanzhou City, China. Renewable Energy, 36, 1431-1436.

Organisation for Economic Co-operation and Development/International Energy Agency (OECD/IEA) (2005). Energy statistics. ManualL - 2920 Luxembourg: EUROSTAT.

Parshall, L., Gurney, K., Hammer, S. A., Mendoza, D., Zhou, Y., \& Geethakumar, S. (2010). Modelling energy consumption and $\mathrm{CO}_{2}$ emissions at the urban scale: Methodological challenges and insights from the United States. Energy Policy, 38, 4765-4782.

Pereira, I. M., \& de Assis, E. S. (2013). Urban energy consumption mapping for energy management. Energy Policy, 59, 257-269.

Pérez, J., de Andrés, J. M., Lumbreras, J., \& Rodríguez, E. (2018). Evaluating carbon footprint of municipal solid waste treatment: Methodological proposal and application to a case study. Journal of Cleaner Production, 419-431.

Phdungsilp, A. (2010). Integrated energy and carbon modeling with a decision support system: Policy scenarios for low-carbon city development in Bangkok. Energy Policy, $38,4808-4817$.

Poggi, F., Firmino, A., \& Amado, M. (2017). Assessing energy performances: A step toward energy efficiency at the municipal level. Sustainable Cities and Society, 33, 57-69.

Rosenzweig, C., Solecki, W., Hammer, S. A., \& Mehrotra, S. (2010). Cities lead the way in climate-change action. Nature, 467(7318), 909.

Schulz, N. B. (2010). Urban energy consumption database and estimations of urban energy intensities. Laxenburg, Austria: International Institute for Applied Systems Analysis (IIASA).

Steemers, K. (2003). Energy and the city: Density, buildings and transport. Energy and Buildings, 35, 3-14.

United Nations (UN) (2014). World urbanization prospects. 2014 Revision. New York: United Nations, Department of Economic and Social Affairs. Population Division.

United Nations Human Settlements Programme (UN-HABITAT) (2008). State of the world's cities 2008/2009. Harmonious cities. London: United Nations Human Settlements Programme.

Vedrenne, M., Borge, R., Lumbreras, J., Rodríguez, M. E., de la Paz, D., Pérez, J., .. Quaassdorff, C. (2016). A comprehensive approach for the evaluation and comparison of emission inventories in Madrid. Atmospheric Environment, 145, 29-44.

Webb, J., Hawkey, D., \& Tingey, M. (2016). Governing cities for sustainable energy: The UK case. Cities, 54, 28-35.

Winkler, H., Borchers, M., Hughes, A., Visagie, E., \& Heinrich, G. (2017). Policies and scenarios for Cape Town's energy future: Options for sustainable city energy development. Journal of Energy in Southern Africa, 17, 28-41.

World Resources Institute (WRI) (2014). Global protocol for community-scale greenhouse gas emission inventories. An accounting and reporting standard for citiesWorld Resources Institute, C40 Cities Climate Leadership Group and ICLEI Local Governments for Sustainabilityhttp://www.wri.org/publication/global-protocol community-scale-greenhouse-gas-emission-inventories.

Yu, H., Pan, S. Y., Tang, B. J., Mi, Z. F., Zhang, Y., \& Wei, Y. M. (2015). Urban energy consumption and $\mathrm{CO}_{2}$ emissions in Beijing: Current and future. Energy Efficiency, 8, 527-543.

Zhao, X., Li, N., \& Ma, C. (2012). Residential energy consumption in urban China: A decomposition analysis. Energy Policy, 41, 644-653. 